\title{
Experimental investigation of a draft tube spouted bed for effects of geometric parameters on operation
}

\author{
Azizaddini, Seyednezamaddin; Lin, Weigang; Dam-Johansen, Kim
}

Published in:

AIP Conference Proceedings

Link to article, DOI:

$10.1063 / 1.4951799$

Publication date:

2016

Document Version

Publisher's PDF, also known as Version of record

Link back to DTU Orbit

Citation (APA):

Azizaddini, S., Lin, W., \& Dam-Johansen, K. (2016). Experimental investigation of a draft tube spouted bed for effects of geometric parameters on operation. AIP Conference Proceedings, 1738, [030043].

https://doi.org/10.1063/1.4951799

\section{General rights}

Copyright and moral rights for the publications made accessible in the public portal are retained by the authors and/or other copyright owners and it is a condition of accessing publications that users recognise and abide by the legal requirements associated with these rights.

- Users may download and print one copy of any publication from the public portal for the purpose of private study or research.

- You may not further distribute the material or use it for any profit-making activity or commercial gain

- You may freely distribute the URL identifying the publication in the public portal

If you believe that this document breaches copyright please contact us providing details, and we will remove access to the work immediately and investigate your claim 


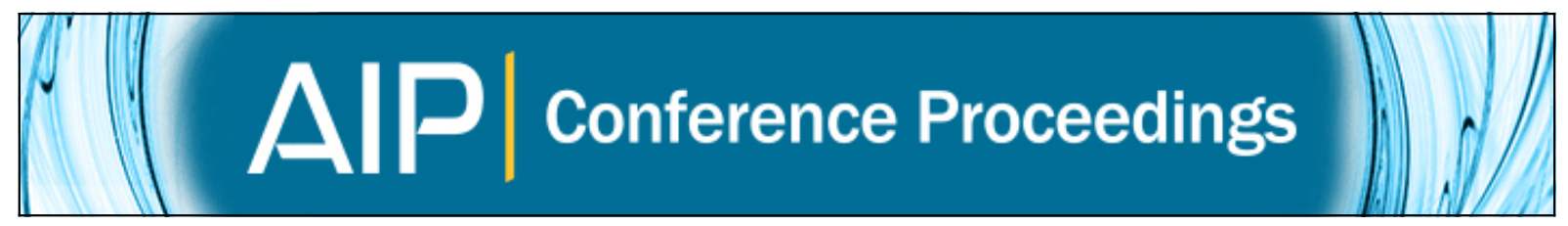

\section{Experimental investigation of a draft tube spouted bed for effects of geometric parameters on operation}

Seyednezamaddin Azizaddini, Weigang Lin, and Kim Dam-Johansen

Citation: AIP Conference Proceedings 1738, 030043 (2016); doi: 10.1063/1.4951799

View online: http://dx.doi.org/10.1063/1.4951799

View Table of Contents: http://scitation.aip.org/content/aip/proceeding/aipcp/1738?ver=pdfcov

Published by the AIP Publishing

\section{Articles you may be interested in}

Experimental and numerical investigation of a draft tube cone at lower runner speeds

AIP Conf. Proc. 1738, 030019 (2016); 10.1063/1.4951775

Investigating particle phase velocity in a 3D spouted bed by a novel fiber high speed photography method AIP Conf. Proc. 1547, 289 (2013); 10.1063/1.4816878

Effect of cohesion on granular-fluid flows in spouted beds: PIV measurement and DEM simulations AIP Conf. Proc. 1542, 979 (2013); 10.1063/1.4812097

Experimental analysis and visualization of spatiotemporal patterns in spouted fluidized beds Chaos 14, 499 (2004); 10.1063/1.1739012

Investigation of effective geometrical parameters for a pulse-echo linear array with cylindrically curved, focusing surface

J. Acoust. Soc. Am. 105, 1291 (1999); 10.1121/1.426153 


\title{
Experimental Investigation of a Draft Tube Spouted Bed for Effects of Geometric Parameters on Operation
}

\author{
Seyednezamaddin Azizaddini, Weigang Lin and Kim Dam-Johansen \\ Department of Chemical and Biochemical Engineering, Technical University of Denmark, Building 229, 2800 \\ Kgs. Lyngby, Denmark
}

\begin{abstract}
Experiments are performed in a draft tube spouted bed (DTSB) to investigate effects of the operating conditions and the geometric parameters on the hydrodynamics. Geometry parameters, such as heights of the entrained zone, draft tube inner diameter, inner angle of the conical section were studied. Increasing the draft tube inner diameter, sharper inner angle of the conical section and higher height of entrained zone increase the internal solid circulation rate and the pressure drop. Even though, for all different configurations, higher gas feeding rate leads to higher internal solid circulation rate considering a maximum value.
\end{abstract}

\section{INTRODUCTION}

Conventional spouted bed (CSB) is an effective gas-solid contact system for coarse particles [1,2]. Different configuration of spouted beds were applied to improve the spouting performance, gas-solid contact, solid circulation rate and gas flow distribution [3, 4, 5]. Cylindrical-conical [6, 7], rectangular-pyramidal [8, 9] and conical configurations [4] are the examples of modifications on conventional spouted beds. Inserting a tube to the spouting stream of a CSB will form a draft tube spouted bed (DTSB) [1].

DTSB has advantages on stability, flexibility and controllability of the gas and solid residence time, internal solid circulation rate and gas flow distribution. Thus, the DTSB systems are widely utilized in different industries, e.g. gasification [10], pyrolysis [11], pharmaceutical [12, 13], particle drying [7], mixing and coating [6, 8]. A systematic study is required on a DTSB to investigate effects of the operating conditions and geometric parameters on hydrodynamics to fulfil lack of a consistent and comprehensive data base.

In this study, effects of operating conditions such as particle size and total gas flow rate, and geometric parameters such as diameter of the draft tube, height of entrained zone and angle of the conical section are investigated on hydrodynamics of a DTSB test rig, parameters such as pressure drop through the dense bed and internal solid circulation rate.

\section{EXPERIMENTAL PROCEDURE}

Experiments were carried out in a lab-scale DTSB set-up, made of transparent Plexiglass ${ }^{\circledR}$ to facilitate visual observation qualitatively and quantitatively. The test rig comprises of two sections, a conical-cylindrical tube as annular section and a cylindrical tube as draft tube section, as illustrated in Figure 1. The cylinders are mounted coaxially while the gap between bottom of the draft tube and the cone (height of entrained zone) is adjustable. The alternative design parameters are stated as in Table 1 where total height of the device, diameter of the annular section and height of the draft tube are 350, 60 and $125 \mathrm{~mm}$, respectively.

Particle sets in narrow size ranges were prepared for performing the experiments. Samples are quartz sand (sea shore sand) particles in size range of (125-212), (212-350), (350-500), (500-707), (1000-2000) and (2000-2360) $\mu \mathrm{m}$.

Two pressure transducers record the pressure difference between bottom and top of the dense bed, pressure indicators PI1 and PI2. Internal solid circulation rate (ISCR) in the draft tube and annular section are equal while the set-up is operated under steady state condition. The ISCR is calculated by measuring the descending velocity of a tracer particle on outer wall of the annular section. 


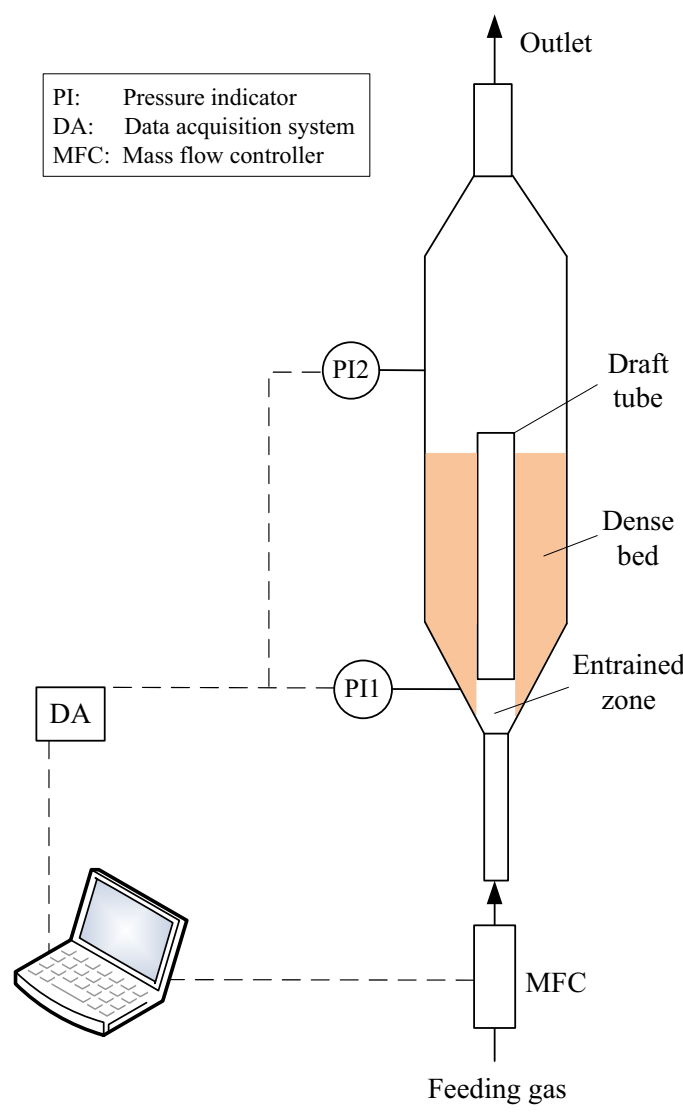

FIGURE 1. Draft tube spouted bed test rig

TABLE 1. Alternative geometric parameters of the DTSB

\begin{tabular}{lccc} 
Parameters & Symbols & Unit & Values \\
\hline Annulus diameter & $D_{A N}$ & $\mathrm{~mm}$ & 60 \\
Inner angle of the cone & $\alpha$ & degree & 55,80 \\
Diameter of draft tube & $D_{D T}$ & $\mathrm{~mm}$ & 14,17 \\
Height of draft tube & $H_{D T}$ & $\mathrm{~mm}$ & 125 \\
Height of entrained zone & $H_{E Z}$, & $\mathrm{mm}$ & $20,30,40$ \\
\hline
\end{tabular}

\section{RESULTS AND DISCUSSION}

\section{Pressure Drop}

Figure 2 shows the pressure drop as a function of gas flow rate (a) with different particle sizes and (b) various combination of the geometric parameters. Vertical axis, in Figure 2, is the pressure drop through the unit height of the dense bed $\left(\triangle P / H_{D B}\right)$ and horizontal axis shows the total gas feeding rate in standard liter per minute $(S L P M)$. At higher total gas flow rates, pressure drop decreases which represents lower flow of the gas to the dense bed in the annular section. Only variable parameter in Ergun correlation [14], see Equation 1, is gas velocity and while the other parameters (void and particle size) are constant, lower gas velocity results in lower pressure drop.

$$
\frac{\Delta P}{H_{D B}}=150 \frac{(1-\varepsilon)^{2}}{\varepsilon^{3}} \mu_{g} \frac{V_{g}}{d_{p}{ }^{2}}+1.75 \frac{(1-\varepsilon)}{\varepsilon^{3}} \rho_{g} \frac{V_{g}^{2}}{d_{p}}
$$

From Figure 2-(b), it is shown that sharper angle of the conical section leads to lower pressure drop which can be implied as lower distribution of the feeding gas to the annular section. Larger height of the entrained zone shifts the 
minimum stable spouting velocity (where pressure drop is minimum and internal solid circulation rate is maximum) to higher gas feeding rates and also is contributed to higher pressure drop. It takes place considering higher possibility of gas flow to the dense bed due to larger entrained zone. Smaller diameter of the draft tube causes operation under lower gas feeding rates and less sensitivity of pressure drop to the total gas flow rate.

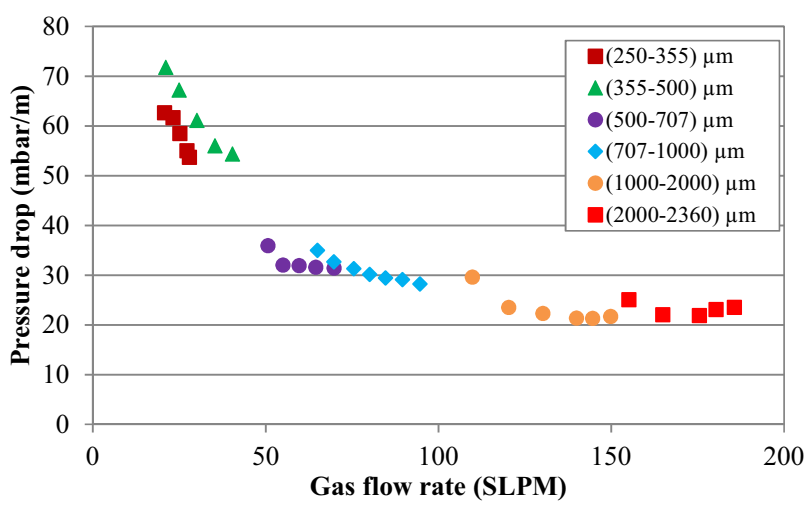

(a)

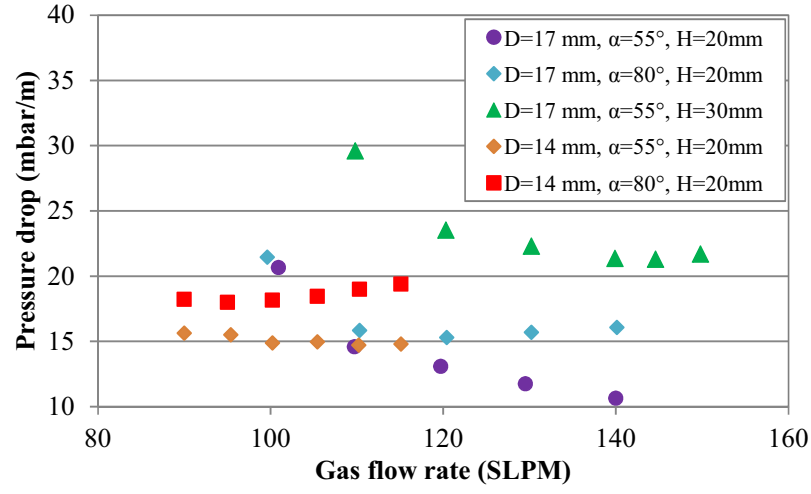

(b)

FIGURE 2. Pressure drop over the draft tube spouted bed. (a) Different particle sizes, (b) Various geometric parameters

\section{Internal Solid Circulation Rate (ISCR)}

Internal solid circulation rate is measured considering the particle velocity on the outer surface of the annular section along the first $5 \mathrm{~cm}$ from top of the moving dense bed. It assumes that velocity of the single particle represents the velocity of the moving bed in the cylindrical part of the annular section [5]. ISCR results of different particle sizes in the DTSB set-up are represented in Figure 3-(a). ISCR increases by increasing the total gas flow rate. This trend reaches a maximum which is corresponded to the minimum stable spouting condition.

Figure 3-(b) shows the effect of combination of the geometric parameters on ISCR. Sharper angle of the conical part increases the ISCR and shifts the maximum ISCR to lower gas flow rates. It takes place due to lower restriction of the particles flow from the cylindrical part of the annular section down to the entrained zone. Larger height of the entrained zone leads to higher ISCR and it also can be explained by lower restriction against the flow of particles to the entrained zone which particles may easily be washed to the draft tube and transported upward. Higher ISCR is experienced for a draft tube with a larger diameter due to larger surface area of the tube.

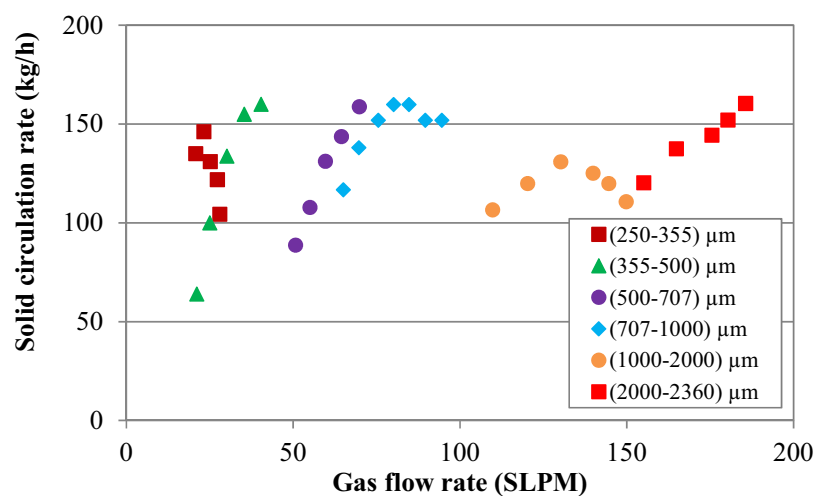

(a)

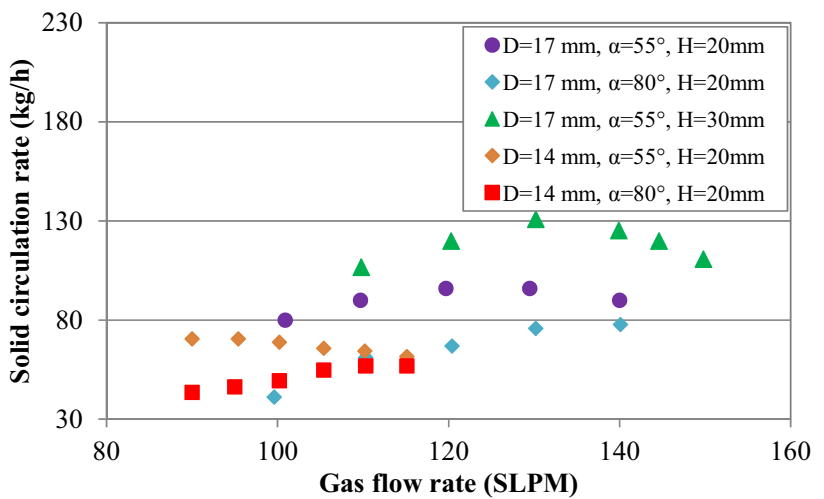

(b)

FIGURE 3. Internal solid circulation rate. (a) Different particle sizes, (b) Various geometric parameters 


\section{CONCLUSION}

Investigation on hydrodynamics of a DTSB bed reveals that:

- Larger height of the entrained zone leads to a higher pressure drop which implies as flow of higher fraction of the gas to the annular section, and also higher solid hold-up in the draft tube which represents as higher ISCR.

- Changes on inner angle of the conical section has a direct influence on pressure drop and indirect effect on ISCR which it might be explained by higher restriction against the flow of particles from the annular section to the entrained zone.

- Larger diameter of the draft tube is contributed to lower pressure drop but higher ISCR. It is resulted from larger surface area of the tube which leads to lower restriction against the flow of gas and solid therefore lower pressure drop and higher ISCR take place.

- Distribution of the gas between the draft tube and the annular dense section is also estimated from the pressure drop data and application of the Ergun correlation.

Possible comparison of the present results with the former studies represents a good agreement on the trend of changes on pressure drop and internal solid circulation rate.

\section{ACKNOWLEDGEMENT}

The authors appreciate the chemical and biochemical department of the Technical University of Denmark (DTU) for financial support of the project.

\section{REFERENCES}

1. H. Nagashima, T. Ishikura, and M. Ide, Korean Journal of Chemical Engineering 16, 688-693 (1999).

2. H. Altzibar, I. Estiati, and M. Olazar, Influence of the Geometric Factors of Conical Contactors and Draft Tubes on the Performance of Draft Tube Conical Spouted Beds, vol. 32, Chemical Engineering Transaction, 2013.

3. C. R. Duarte, V. V. Murata, and M. A. S. Barrozo, Brazilian Journal of Chemical Engineering (2008).

4. H. Altzibar, G. López, M. J. S. Jose, S. Alvarez, and M. Olazar, "Drying Of Fine Sand In A Pilot Plant Unit Provided With A Draft-Tube Conical Spouted Bed," in The $10^{\text {th }}$ Conference on Process Integration, Modelling and Optimisation for Energy Saving and Pollution Reduction, 2007, pp. 1-6.

5. H. Nagashima, K. Suzukawa, and T. Ishikura, Particuology 11, 475-482 (2013).

6. X.-L. Zhao, Q. Yao, and S.-Q. Li, Chemical Engineering \& Technology 29, 875-881 (2006).

7. Z. Arsenijevic, Z. Grbavcic, and R. Garic-Grulovic, Journal of the Serbian Chemical Society 71, 401-412 (2006).

8. M. Kalwar, G. Raghavan, and A. Mujumdar, Powder Technology 77, 233-242 (1993).

9. S. Prachayawarakorn, S. Ruengnarong, and S. Soponronnarit, Journal of Food Engineering 76, 327-333 (2006).

10. Y. Hatate, H. Mihara, K. Ijichi, T. Yoshimi, S. Arimizu, Y. Uemura, and D. F. King, Process systems engineering. catalytic coal gasification using a draft tube spouted bed gasifier (1996).

11. J. H. Eng, W. Y. Svrcek, and L. A. Behie, Industrial \& Engineering Chemistry Research 28, 1778-1785 (1989).

12. Y. Fukumori, and H. Ichikawa, Microencapsulation of pharmaceuticals by fluidized bed process. apparatus, material and particulate designs. (1997).

13. P. Deepa, M. Parande, S. Attar, D. Sathiyamoorthy, and P. K. Mollick, International Journal of Pharmaceutical, Chemical and Biological Science 3, 870-875 (2013).

14. S. Ergun, Chemical Engineering Progress 48 (2), 89 (1952).

15. H. Altzibar, G. Lopezy, M. Olazarz, and J. Bilbao, "Study of The Minimum Spouting Velocity in A Draft Tube Conical Spouted Bed," in The $13^{\text {th }}$ International Conference on Fluidization - New Paradigm in Fluidization Engineering, 2010, pp. $1-8$. 